\title{
EXPERIMENTAL INVESTIGATIONS OF MULTIBLADE WIND WHEEL MODEL
}

“National Mining University” State Education Institution, 19, O. Pol Avenue, 49005, Dnepr, Ukraine; e-mail: botticelli@i.ua

The majority of the existing techniques for studying the characteristics of physical models of wind generators are oriented on the use of the specialized equipment and a wind tunnel. In some cases, these investigations are too expensive or unattainable. Transportation of the wind wheel model with the required velocity is alternative to such studies. The study objective is to determine the mechanical characteristics of a physical model of a horizontal-axial wind wheel based on the results of measurements during transportation of the model with the required velocity. The mechanical characteristics to evaluate the wind wheel effectiveness, the most efficient operational conditions related to the wind velocity, requirements for the electrical generator parameters have been resulted from studies.

The wind velocity as a component of the incoming airflow near the blades in a relative motion is considered as a factor resulted in the rotation, and a radial velocity of an elemental blade portion is a consequence of the effects of the wind velocity and is able to counter the rotation. Torques about the wind wheel axis due to those components are found. The resulting torque in the wind wheel axis is determined as the sum of torques of the incoming airflow components in a relative motion.

Practically, while transporting the wind wheel under wind calm conditions, we measure the velocity of the incoming airflow, the force produced by the airflow in axis of the wind wheel, a maximal rotational speed of an unloaded wind wheel. From measurements, we derive the real mechanical characteristics of the wind wheel under consideration.

Keyords wind power plant, multiblade wind wheel, aerodynamics, mechanical characteristics, experimental investigations, physical model.

1. Obukhov S. G. Method of Simulation of Mechanical Characteristics of Low-Powered Wind Turbines. Vetroenergetika. 2011. No 1. Tomsk: TPU Publishing House, 2011. 142 p. (in Russian)

2. Faraponov V. V., Savkina N. V., Dyachkosky A. S., Chupashev A. V. Computations of body drag coefficient in subsonic and transonic conditions using ANSYS Fluent package. Komputernye Issledovania i Modelirovania. 2012. Vol. 4. No 4. P. 845 - 853. (in Russian)

3. Andrianov V. N., Bystritskiy D. N., Vashkevich K. P., Sektorov V. P. Wind-Power Stations. Edited by Prof. V. N. Andrianov. M.: Gosenergoizdat, 1960. 324 p. (in Russian)

4. Kravets A. S. Characteristics of Aviation Profiles. M.: Governmental Publishing House of Defense Industry, 1939. (in Russian)

5. Yakovlev A. I., Zatuchnaya M. A. Aerodynamic Calculations of Wind Propeller-Type Turbines. Kharkov: "Kharkiv Aviation Institute" National Aerospace University, 2001. 78 p. (in Russian) 